\title{
The Influence of the "Learning from Success" Method on the Feeling of Self-Capability and Motivation for Success among Special Admissions College Students
}

\section{Zeev Greenberg}

Tel Hai College

E-mail: greenbrg@telhai.ac.il

\author{
Doi:10.5901/jesr.2013.v4n3p389
}

\begin{abstract}
This article describes use of the "Learning from Success" method with college students, after successful completion of their first semester of studies. The participating students were admitted under a lower acceptance threshold and received academic support for core courses in a special support program. The use of the Learning from Success method enabled retrospective learning and in-depth examination of the actions that brought about their success on examinations, as well as articulation of study methods that will enable the students to replicate their success in the future. The action research conducted enables examination of the Learning from Success method and its use with students. The article presents the findings from a retrospective inquiry into the success of students who have difficulty in their studies, the feeling of competence and motivation that the success generated in them and the value of the inquiry according to the Learning from Success method for personal empowerment of the students. The article contributes to existing knowledge about academic support for students with learning difficulties in two primary ways: First, the article presents working methods that help the students form an identity as normative students who achieve success in their studies. Second, the article explains working methods that enable the defining and coalescing of learning strategies that enable the students to replicate their learning successes in the future.
\end{abstract}

Keywords: Learning from Success; higher education admissions; academic support

\section{Introduction}

This article presents results from the use of the "Learning from Success" method with college students accepted under a lower admissions threshold and who were identified as being at high risk for attrition in the first year of their studies. These students are accepted conditionally and their academic achievements must be sufficiently high at the end of their first year of studies in order to maintain enrollment status.

The research findings contribute in two areas. The first contribution is to the identification of learning processes and academic support methods for students who have difficulty learning. The second is the examination of the use of the "Learning from Success" method and its influence on the students' ability to feel successful in their studies. The article will present recommendations for processes that enhance examination preparation for students who have difficulty in their studies, as well as recommendations for implementing the "Learning from Success" method as a means for enhancing the feeling of success and learning capability among them.

\section{Literature review}

\subsection{Absorption into higher education of students who have difficulty learning}

At institutions of higher learning acceptance criteria are based upon past achievements (Beller 2001; Boyer, 1987). As part of the social role of academia, students with difficulties learning are granted admission according to reduced admissions criteria and they are required to prove their academic abilities during the first year of their studies (Chemers, Hu \& Garcia, 2001; Clark, 1986; McKenzie and Schweitzer, 2001). Many of these students lack learning skills and experience in independent learning and carry with them memories of unsuccessful learning in the past.

The overarching goal of the project described in this article was to enable students accepted for study in the Departments of Science and Social Science and Humanities under low admissions criteria to reach learning achievements in their first year of study that would prevent their attrition from higher education. To meet this goal, a 
program of academic support and acquisition of learning skills was implemented to assist students in maximizing their personal potential and strengthening their self-image.

\subsection{Conditions for enhancing motivation for learning}

In recent decades interest has increased in the intrinsic and extrinsic factors that contribute to the development of motivation for learning (McKenzie \& Schweitzer, 2001; Soric, 2009). Theories of motivation have been developed to explain which factors promote student diligence in their studies. The majority of research in the area of educational motivation has been conducted with elementary and secondary school students and only a small number of studies examine the motivation of college students. Theories examining motivation for learning either examine motivational strength on a scale ranging from amotivation to high motivation or differentiate between intrinsic and extrinsic motivation (Deci \& Ryan, 1985, 2000). These two different types of motivation operate independently of each other (Henderlong \& Lepper, 2002). This latter theory provides a framework for understanding the dynamic of different motivations and attempts to examine their origin and outer limit of effectiveness and durability (Pintrich \& Schunk, 2002; Weiner, 1989).

One of the theories relating to the dynamic of motivations is the self-determination theory (Deci, 1991; Deci \& Ryan, 1985, 2000), based upon a sociological approach that presents two poles for the motivational scale: extrinsic motivation and intrinsic motivation. According to the self-determination theory, the more intrinsic the motive the greater the quality of the motivation (Deci, Vallerand, Pelletier \& Ryan, 1991). Furthermore, the learner is influenced greatly by his or her peer group and its values, the academic faculty, including teachers and teaching assistants and by existing techniques of support in the student's educational institution (Daniels \& Arapostathis, 2005; Deci, 1991; Deci, Koestner \& Ryan, 2001; Oplatka, 2007).

Many researchers (Gottfried, 1985; Hidi \& Harackiewicz, 2000; Krapp, Hidi \& Renninger, 1992; Pintrich \& Schunk, 2002; Waugh, 2002) have demonstrated that intrinsic motivation of the learner influences the extent of in-depth learning and the use of learning strategies.

From here, one can see that understanding the processes that promote success, their replication and the turning of them into operative values will lead to educational success and this, in turn, can promote development of intrinsic motivation for learning.

\subsection{Reflective learning}

Reflective learning is the learning process by which learners analyze and interpret new situations that develop over the course of the process, critique their practices and change their actions in light of their interpretation. This is a dialogue that happens between learners and themselves. Schon (1987) defined three dimensions of reflective learning: reflection on an action after its execution (reflection on action), reflection on an action while it is occurring (reflection in action) and the constructing of future modes of operation in preparation for action (reflection for action).

The "Learning from Success" method is a method based upon reflective learning from past actions and making the knowledge gained operative according to theories of action (Argyris \& Schon, 1974; Schon, 1991). The theory holds (Gottfried, 1985; Hidi \& Harackiewicz, 2000; Krapp, Hidi \& Renninger, 1992; Pintrich \& Schunk, 2002; Waugh, 2002) that using a past success for learning toward future action, through reflection on that action and its examination, enables the turning of tacit knowledge into actionable knowledge for the future (Schechter, Sykes and Rosenfeld, 2008).

\section{4 "Learning from Success" Method}

The "Learning from Success" method is customarily used by professional staffs (Ellis, Mendel \& Nir, 2006). The method emphasizes the experience gained by the learner and the members of her group and the turning of the experience into revealed knowledge of the group. This is achieved by conducting inquiries, reflective learning and articulation of future methods of action that will enable successful managing of similar, future events (Kruse, 2001). There is substantial documentation of the method's use among teachers and professional staff of high schools for the purposes of staff learning and the professional advancement of teachers and principals in their workplace (Greenberg \& Cohen, 2012; Schechter, 2010; Schechter, Sykes \& Rosenfeld, 2004, 2008). However, no documentation has been found for the use of the method with first-year college students coping for the first time with academic learning.

This research describes the use of the "Learning from Success" method with students who successfully completed their final course examinations in the first semester of their academic studies. Implementation of the method was based 
upon an investigative process containing nine stages: 1) identifying a success worthy for study and defining the area of success; 2) describing, succinctly, the success in terms of "before" and "after"; 3) examining both the objective and subjective, positive outcomes of the success; 4) identifying the costs of the success - identifying negative by-products; 5) assessing whether the success being examined justifies continuing the learning; 6 ) detailing the actions that led to the success; 7) identifying turning points between "before" and "after"; 8) determining the common elements at the foundation of the actions that led to the success; and 9) identifying unresolved issues for continued learning (Schechter, 2010; Sykes, Rosenfeld \& Weiss, 2006).

\section{5 "Learning from Success" method as implemented in current research}

The stages of the "Learning from Success" method were adapted for the college student group in the current action research.

\subsubsection{Identifying a success worthy for study}

This stage involved a) identifying first-year students from among those receiving academic support who defined their first semester final grades as a success; b) organizing the identified students into a working group according to the "Learning from Success" method; and c) explaining the method, its significance and the goals of the working group.

\subsubsection{Describing, succinctly, the success in terms of "before" and after"}

In this stage, working in pairs, each student was asked to describe, in his or her opinion, what led to success on the examinations, with an emphasis on study methods. The goal of this stage was to amplify the significance of the success and to create communication based upon cooperation and honesty between the group members.

\subsubsection{Examining the positive outcomes of the success}

Working in pairs, the students conducted an inquiry of each other using a structured questionnaire based on the principles of the "Learning from Success" method. The students prepared PowerPoint presentations of their inquiry results, which they presented to the group. The presentations focused upon the decisions and actions that, in their opinion, led to success in their studies. This stage was significant on the individual level (acquisition of a learning tool and development of personal responsibility for their learning) and on the group level (group cohesion, creation of a positive learning atmosphere and mutual help during the group learning).

\subsubsection{Identifying the costs of the success, identifying negative by-products}

In this stage, a discussion was held in the large group based upon the presentations. The inputs required to achieve the success were examined, including the amount of time and resources invested. Attention was given to uncertainties and moments of crisis that each student experienced during study.

\subsubsection{Crossroads on the journey - identifying turning points on the journey to success}

In this stage, the students examined the turning points and crossroads at which they made decisions that advanced learning that led to success. Decisions were emphasized that dealt with active conduct and learning methods in academic courses, with academic support received and with studying for final examinations.

\subsubsection{Determining principles of action enabling replication of the success in the future}

In this stage, that began in small groups and continued in the full group, the students articulated the actions leading to the success as principles and as modes of action that would lead to future success. The principles of action were articulated in precise detail and presented to the entire group, in order to expose every student to the knowledge gained by their peers in the group. 


\subsubsection{Identifying unresolved issues for continued learning}

In this final and concluding stage in the work of the group, the students examined questions raised that remained unanswered, as well as issues that were not considered in the earlier, large group discussions with potential for advancing future learning.

\section{Methodology}

The type of research presented here is "Action Research" of a group operating according to the "Learning from Success" method. The research accompanied the group activity in the three inquiry stages: the discussions in pairs, the PowerPoint presentations of the inquiries and the large group discussions during which the group articulated action principles for the future. The researchers analyzed the products of the group work: tapes of the discussions, student PowerPoint presentations of their inquiry results and the in-depth interviews conducted with students throughout the program and at its conclusion.

\subsection{Research population}

The fifty-four students who participated in the research were identified at their acceptance to the college as having a lower admissions threshold and as being at risk for dropping out from higher education studies according to prior research findings. The student group included 25 students from the Department of Sciences and 29 students from the Department of Social Sciences and Humanities. Twenty-three of the students are the first generation in their families to go on to higher education. Out of the group, 33 students are the grandchildren of immigrants who arrived in Israel in the early fifties and seven students are the children of first generation immigrants to Israel.

\subsection{Research procedure}

After receiving their final grades, all students who received academic support during their first semester of studies were asked whether they defined the grades as a success. Students who responded positively were invited to participate in a "Learning from Success" action group. The students received an explanation of the goals of the workshop, its importance for their continued future success, the expected length of the activity and the working methods to be employed. The facilitator of the action group is an expert who previously implemented the "Learning from Success" method in high schools. In addition to the group facilitator, a researcher accompanied the project who documented the process and gathered the group materials. These materials included transcriptions of the recorded group discussions and the PowerPoint presentations of the findings from the inquiries into student learning in preparation for examinations. The inquiry questionnaires and PowerPoint presentations were structured according to the elements of the "Learning from Success" method as presented in the section above describing the stages of the method as implemented in the current research (Schechter, Sykes \& Rosenfeld, 2008; Weiss, Gavish, Rosenfeld, Ellenbogen-Rankovits \& Sykes, 2007).

\subsection{Research tools}

This research is based upon three primary research tools: twenty-seven PowerPoint presentations of the inquiries conducted in pairs, transcriptions of the group discussions and in-depth interviews conducted with students who participated in the activities of the group. The information was analyzed by the writer of this article and broken down into logical units or themes by which factors advancing student success in their studies were identified, as well as factors reflecting the contribution of the "Learning from Success" method to student feelings of success. At the same time, themes representing difficulties in both processes were identified. Following this analysis, a discussion was held between the group facilitator and the researcher who accompanied the group throughout its activities implemented in order to word the agreed upon themes.

\section{Findings}

The research findings presented here deal with the importance of success both in affirming to students that they are able to integrate into higher education and are capable of being successful students. The grades from the students' first 
semester of studies became an intersection between the past and the present - and they now define themselves as student learners. The students reported that the academic support they received including: personal mentoring from senior students, academic help from professional instructors and intensive exam preparation courses, helped them study, enhanced their motivation for autonomous learning and contributed to their confidence as learners. It was found that the inquiry questionnaires conducted according to the "Learning from Success" method contributed to the students' internalization that learning is a structured process, there are proper learning tools and that learning is individual. In the course of the group work, the students were exposed to a variety of learning methods and study plans carried out by their peers. It was also found that the group activities were meaningful to its members. The group discussions and activities enabled students to contribute to others from their own knowledge and to become enriched by the variety of new learning methods with which they were previously unfamiliar. In the sub-sections that follow, the themes arising from the research findings are presented in detail.

4.1 The success of the students on final exams in their first semester of study is the first experience constituting proof that they are able to study and achieve academic success.

The majority of students related to the feeling of success in their studies as a first-time experience. One student described the feeling of success and its novelty for him when he said:

"I never thought of myself as being successful, and I also couldn't say to myself whether I came out of the exam with a good feeling, but when I saw the grade, I understood that I had succeeded. If in a course like this I pulled a grade above seventy, it means that I succeeded, that I know the material, that I know how to learn".

Another student said:

"All of the studying and preparation before gave me a feeling of confidence before the exam. I didn't come bummed out, I knew that I know the material, I studied seriously, am familiar with the terms. Not like in the past when I would just show up to the test, I came with readiness and preparedness".

Another student compared his past situation to his present situation and said:

"In the past, even when I really invested in studying, in the end there were always disappointments, so I didn't really believe, I went to the reinforcement classes and I did everything you are supposed to do. But I prepared myself; I knew that in the end the blow would come...just as I was used to from before...from school. When I entered the first exam, I looked at the questions and I said to myself, 'I know the material I will succeed', but I didn't really believe in it."

Yet another student described the feeling when he said:

"The grade I got on the exam was more than I expected, in the past, if I got a passing grade, I was happy. This grade was like a road sign for me, from here I already know how to continue".

The influence of the success on motivation to continue studying was described by another student when he said: "When I saw the grade from the first exam it caused me to continue and invest also in the other exams, also in the papers. It really was like giving me new strength when I began the second semester". Another student said: "It's a great feeling. Suddenly you have drive. I got a good grade, it made me continue and invest". Relating to motivation, another student claimed: "That feeling that I succeeded is an amazing feeling, something sweet that spreads through the whole body...it produces the desire to continue, to work and invest in order to succeed again....and again...it is a wonderful feeling".

The interviews teach about the meaning of success in the eyes of the participating students. In the majority of interviews, the comparative aspect arose between their past identities as students and their current feeling of success, revealed as something new for some of them. One can conclude that the students began their higher education with low faith in their academic capabilities and that this feeling accompanied some of them as they coped with their first semester studies. It appears that the first-semester final exam grades are proof and confirmation for the students that they have academic capability and can succeed as learners. The learning achievements that they were unaccustomed to in the past are their success. The student statements also teach that their studying prior to the exams increased their 
knowledge of the material and enhanced their feeling of preparedness for the test. These, in turn, influenced their selfconfidence upon arriving at the test.

4.2 The significance of the academic support received and its influence on the development of motivation and autonomous learning of the students.

The significance of the academic support received was given expression by the students in their PowerPoint presentations of the inquiries they carried out in pairs. It was further underscored in the in-depth interviews conducted with them throughout the process. One student stated in her interview that:

"On the first day I was in shock, we sat in a huge class of over one-hundred students, the fears straightaway and what if I won't understand? And what if I won't know? ... There is no way I would I raise my hand and ask, that's not my personality...I would sit quietly and not say a word and for sure not in a class that size".

Another student spoke in her interview about the advantages of the personal tutoring for the large introductory courses: "From my perspective, the personal tutoring was the solution. I was able to ask, not to be embarrassed to request that they explain it to me again and again".

Another student related to the advantages of the personal tutoring that he received when he said:

"In class I didn't dare ask questions, I was afraid that they would think that I didn't understand or didn't know, I was afraid that the lecturer would discount me. In my meetings with my tutor, I felt comfortable to ask any question, even a question that I thought wasn't intelligent. That's why I have a tutor...to learn...so I ask freely".

Later in the interview he clarified:

"Lots of times when I was meeting with my tutor I got why I didn't understand in class, there the lecturer ran with the material...you don't have a chance to understand and he is already on the next topic. With the tutor it was enough that I would say one word from the lecture and straightaway I would get an explanation and that is what suited me, the private explanation, alone, at a pace that fit me."

Yet another student described this feeling when she said: "My tutor had a lot of patience and I felt really comfortable with her. I asked questions and I would request that she explain again and she had so much patience for me." Another student emphasized the advantages of tutoring when he said: "Only with my tutor did I feel free to ask questions, to understand. We sat in pairs, one would ask and one would answer...that gave me a good feeling. I said to myself, here, it's going well for you, which helped me a lot".

An additional type of academic support to which the students referred was "marathon" exam preparation courses. These small group courses were given by teaching assistants shortly before the exam period to help students succeed on their final exams. The courses are called "marathons" because the teaching assistant "runs" with the course material, explaining terms and then leading students through practice questions from previous exams.

In relating to the influence of the marathon courses on their exam successes, one student said: "The marathon is like an energy shot before the test - you come, you learn, you review the important material in a concentrated way, practice and understand". Another student related to the study skills that he received in the marathon course when he said:

"We received a precise explanation as to how to read the question, to understand what they are asking of us, and how to begin answering it...I never knew that you have to know how to read the question and to mark what they are asking...that made me see the question differently and that is also how I answered the question...it really helped...that was an innovation for me".

Another student described the advantages of learning in the "marathons" and the advantages of the small groups when he said: "The teaching assistant explained to each one of us practically personally, so that I heard a number of explanations, and the subject was clearer". Another student said:

"Only in the small group did I feel comfortable to ask questions, to turn [to the teaching assistant] and to try and understand where I made a mistake in the calculations. I felt that the problem was not only mine but everyone's, and it was comfortable to turn and to try and understand what was difficult in the material". 
Another student explained how he connected between the learning in the "marathon" to autonomous learning when he said:

"Before meeting, the teaching assistant asked us to prepare a summary of the important things we learned in the course. And at the meeting he gave us questions and asked us to answer them with the help of the summary of the material from the course. And in the second stage I answered in my head without the summary; this way I succeeded in learning all of the terms for the exam".

In conclusion, one can say that for students who have difficulties learning, "marathon" courses are an effective learning tool. They assist the students in learning the course material, in coping with the exam and in practicing exam questions. For many of the students it was also the first time that they personally received long-term support. They cited the significance of the private tutoring for learning the material from different courses. Specifically, the intimate encounter and acquaintance with the tutor enabled students to overcome the shame connected with not understanding the material learned and with the need to receive repeated explanations. These factors influence the students' learning by strengthening their abilities and contributing to their self-confidence as students.

4.3 Use of the "Learning from Success" method with students and its influence on advancing learning processes and awareness of the learning processes and tools that are significant for each of the students. The group inquiry processes conducted according to the "Learning from Success" method contributed to the meaningfulness of the group for its student members. The group discussions advanced internal learning in the context of learning tools, learning skills and student ability to cope with difficulties.

In the framework of the inquiry conducted in pairs, the students were asked to detail, with the help of a structured questionnaire based on the "Learning from Success" method, what learning methods they used and what they did during their studies that led to positive learning. The outcomes of the inquiry were given in PowerPoint presentations before the entire group. In the research interviews, the students were asked about the contribution of working according to the "Learning from Success" method. One student said in her interview:

"The question asking for detail about the learning activities wasn't clear to me in the beginning, only when I really broke down what I did before what, when I learned using all sorts of methods, I understood that there is a logic that I didn't see before. I had acted intuitively and suddenly I understood that it is a real work method".

Another student said: "After the presentation, in the class discussion, while they were asking us questions, I saw that learning is something planned, it has stages, and is different for different people". Another student made a similar claim in his interview only more detailed: "When I built the presentation and my partner asked me all of the questions, only then did I understand that there is an ordered way that is possible to build, really according to a structured plan for learning". Another student described the significance of the group for him when he said:

"When the others gave their presentations...there were important things, suddenly I understood each student has his own way to learn and remember terms, I never thought of remembering by association, I learned that from someone else in the group from the presentation and I understood that there truly is a method that I didn't know was possible".

Another student said:

"From the presentations I saw that there are many different methods for how to learn, everyone has his own methods...I always thought that you have to read the material a bit, review it and then I would already remember...suddenly I understood that to learn is not only to read. It is a lot of activities that seemed unnecessary to me, personally,...I understood that learning is not only reading".

Another student said:

"I understood that there are many ways to learn, I can try and learn using other ways because it became clear that each of the tutors taught their students different methods...I can use the ways they showed in their presentations and maybe they will suit me". 
In her interview another student said: "During the presentations we saw that there were those with the same method of learning. I found someone from my department and we decided to study together for the exams".

In summary, the students derived a number of advantages from the work of the group. The presentations, the discussions and the exposure of students to the study methods of others helped them understand that learning is a process and that there are activities that promote effective learning that enhances success. The group discussions enabled the turning of effective, individual methods and activities into principles of action that could be copied by others in the group. It also fostered formation of study groups in common courses.

\section{Discussion and Conclusions}

The research findings show that the students' final exam grades from their first semester of studies contributed to the feeling that they can succeed academically. The unique characteristics of the students chosen for the project increase the significance of this feeling of success. More specifically, the significance of academic success for the students is in seeing themselves as normative students. Their achievements and group work contributed to their understanding of the importance of ongoing study throughout the semester. From the interviews it was clear that the varied modes of academic support the students received played a significant role in their academic success. In many of the interviews, students cited the importance of the personal relationship and feeling of confidence to question and ask for repeated explanations during the tutoring and in other support they received. These findings are similar to those of other studies, which demonstrated that the link between teaching faculty and personal support influences the motivation for learning (Daniels \& Arapostathis, 2005; Deci, 1991; Deci, Koestner \& Ryan, 2001; Oplatka, 2007).

The use of the "Learning from Success" method (Baxter, 2001) contributed to and advanced student understanding of the significance of studying and defining for themselves appropriate study methods. The inquiry stage dealt with the organization of learning, the organization of course material covered and study strategies, which were new to many of the students. Some of the students claimed that this was the first time they even thought about how they study. In the framework of the inquiry, specific study methods were examined. The students were given tools and processes for assessing and mapping out their decision making crossroads and for understanding decisions they made to organize their study in preparation for examinations. During the stage of the PowerPoint presentations before the whole group, the students were exposed to the diverse study strategies of their peers. On many occasions the students related to the possibility of adopting study methods that were proven effective by their peers. These findings testify to the value of the group as a learning community and demonstrate the value of sharing knowledge and the relevance of knowledge created among members of the group (Connell \& Wellborn, 1991; Kreber, 2005; Osterman, 2000; Ryan, 1995).

The activities conducted according to the "Learning from Success" method were what turned the group members into a learning community. The inquiry process and presentation building advanced autonomy in learning processes and research development, and these assisted in making the students aware of the learning processes that contributed to their success, both on the individual and group level. The atmosphere created in the tutoring sessions invited questioning and enabled the giving of assistance, in a different, more supportive and less judgmental environment than that of the large lecture hall. These findings support earlier studies (Deci, 2001; Oplatka, 2007; Schechter, Sykes \& Rosenfeld, 2004; Trigwell, Prosser \& Waterhouse) indicating that the style of teaching that is directed at autonomous learning contributes to a rise in intrinsic motivation for learning, to a feeling of capability and to the self-esteem of the learner. In the group discussions and treatment of the presentations there were learning characteristics of a research community: at this stage discussions were held, questions raised and ideas expressed about successful, past learning and discussion of the possibilities of turning the ideas into principles of action likely to enhance academic success in the future. This type of activity enabled real discussion, during which students who have difficulty learning responded to the ideas of their peers, turning tacit knowledge of the group into operative knowledge for its individual members (Garrison \& Anderson, 2003; Garrison, Anderson \& Archer, 2000; Schechter, 2010).

An additional advantage to working in groups is the opportunity it provides for students to express their emotions and feelings. During the discussions, students were invited to express their frustrations and difficulties as well as the feelings accompanying their successes. According to the students who have learning difficulties this was an innovation, as they were not used to such conversation in the regular life of an academic institution. In the accepted discourse, students generally raise issues about instructors and there is much less space for the feelings of students who have learning difficulties. 
Brown and Brown (2006) point out that participation of individual members in the group processes encourages the feeling of giving when they seek to live up to group expectations that are meaningful for them. It appears that the inquiry process, the intimate work of the group members on their presentations and examining the success stories enhanced the feeling of partnership and cooperation between the members. The cooperation was expressed in many statements of intimacy, trust and closeness among the group members. The group learning processes enabled the members to find, on their own, strengths and abilities that were previously unknown to them that may have remained hidden without the benefit of the process. Dealing with a past success enabled them to experience themselves as successful. From here, one can see that working according to the "Learning from Success" method bestows an experience of strength and meaning in areas in which, until now, they had accumulated only numerous frustrations.

\section{Operative Recommendations}

From this research arises the importance of providing academic support for groups of students who have learning difficulties. The small group study and support and the "Marathon" courses before examinations influence the students and enhance their motivation for autonomous learning. Private tutoring has tremendous significance as an aid during academic courses (Perkins, 1993). It is evident that the relationship woven between the tutor and student enables the student to express difficulties, to ask questions and to request repeated explanations without feeling threatened by peers or by the instructors in large lecture classes. In addition, the experience and past success of the tutor serve as a role model for identification and motivation for the student.

Analysis of the different aspects relating to implementing the "Learning from Success" method among the students shows that it is possible to implement the method with students who have learning difficulties. The method enabled identification of success, discussion and clarification of the elements of success and the turning of them into principles of operation that will enhance continued, future success. In addition, it was found that the inquiry conducted in pairs and the large and small group discussions fostered a feeling of openness and belonging among the group members. This, in turn, enabled honest discussion of successes and difficulties and contributed to the creation of a space in which the students could share feelings honestly and transparently without feeling threatened. Furthermore, utilizing the "Learning from Success" method provided an opportunity for the students to be exposed to new and different study methods that they can adopt as they continue their studies.

\section{Research Limitations}

The first limitation of the research relates to the ability to apply the conclusions presented here, which are based on a specific case, to other situations. Notwithstanding the case specificity, it is reasonable to assume that the findings here can be applied to other college student groups.

The second limitation relates to the fact that participation in the research was voluntary; hence we do not have information about students who did not participate. Nonetheless, since the goals of the research were to identify factors assisting in learning and success and to attempt to draw conclusions from the implementation of the "Learning from Success" method among students, it can be assumed that the information gathered meets the research goals.

The final limitation relates to the measure of use of the learning tools received and the use of these tools in the future. Since the article is based upon action research of a group established after final exams in the first semester of the students' academic studies, there is no information yet available on the measure of assimilation and use of these tools in the students' future studies.

\section{Conclusion}

From this research it is possible to learn about the use of the "Learning from Success" method with students accepted to higher education under lowered admission standards. The findings show that the academic support they received and their first semester final grades were defined by them as a success. Many of the students emphasized that this was the first time they experienced a success in learning. For them, their first semester grades are proof that they are successful learners and perhaps even confirmed for themselves that they are normative students. The findings also demonstrate the value of academic support in two key aspects. The first aspect is that of professional support, mentoring and repeated explanations and their value in enhancing learning. The second is the significance of the personal relationship and intimate encounter in the tutoring setting for enhancing the feeling of confidence of the new students. Here they could ask 
questions and deepen their learning, something they held back from doing in the public learning space of the large lecture hall.

The use of the method advanced students who have learning difficulties and enabled them to act according to the principles of a research community. From the group activity and analysis of the presentations and events that contributed to its success it is apparent that among students there was created a feeling of success, belief in learning ability and intrinsic motivation for future learning. It is apparent that processing the knowledge of the success by means of retrospective learning, its analysis and its construction empowered all of these among students who have difficulty in their studies.

During the work implemented according to the "Learning from Success" method, the group became significant for its members. This was demonstrated by the many expressions of feelings of belonging to the group, empathy among its members, caring and intimacy. This fact enabled openness to mutual learning and legitimacy to ask and to be helped by others and created a learning environment and social climate that encouraged studying. It appears that group cohesiveness, interpersonal learning and reflective process enable the individual in the group to undergo processes of change and growth.

In the transition from the retrospective stage in which learning from the past was conducted, to the prospective stage in which the knowledge accumulated was turned into an operative program for the future, the motivation of the group members to disseminate the information gained to other students is impressive. This motivation is witness to the personal strength the participants felt and to the feeling of expertise they acquired during implementation of the "Learning from Success" method.

\section{References}

Argyis, C., \& Schon, D.A. (1974). Theory in practice: Increasing professional effectiveness. San Francisco: Jossey-Bess.

Baxter, M. (2001). A constructivist revision of the measure of epistemological reflection. Journal of College Student Development, 42(6), $520-534$

Beller, M. (2001). Admission to higher education in Israel and the role of the Psychometric Entrance Test: Educational and political dilemmas. Assessment in Education: Principles, Policy \& Practice, 8(3), 315-337.

Boyer, E. L. (1987). College: The undergraduate experience in America. New York: Harper \& Row.

Brown, L. S., \& Brown R. M. (2006). Selective investment theory: Recasting the functional significance. Psychological Inquiry, 17(1), 1-2.

Chemers, M. M., Hu, L.T., \& Garcia, B. F. (2001). Academic self-efficacy and first year college student performance and adjustment. Journal of Educational Psychology, 93(1), 55.

Clark, B. R. (1986). The higher education system: Academic organization in cross-national perspective. University of California Pr.

Connell, J. P., \& Welborn, J. G. (1991). Competence, autonomy, and relatedness: A motivational analysis of self-system processes. In M. R. Gunnar, \& L. A. Sroufe (Eds.), Self processes and Development. The Minnesota Symposium on child psychology, 23 (pp. 43-77).

Daniels, E., \& Arapostathis, M. (2005). What do they really want?: Student voices and motivation research. Urban Education, 40, 34-59.

Deci, E. L. (1991). Motivation and education: The self-determination perspective. Educational Psychologist, 26(3), 325-346.

Deci, E. L., Koestner, R., \& Ryan, R. M. (2001). Extrinsic rewards and intrinsic motivation in education: Reconsidered once again. Review of Educational Research, 71(1), 1-26.

Deci, E. L., \& Ryan, R. M. (1985). Intrinsic motivation and self-determination in human behavior. New York: Plenum.

Deci, E. L., \& Ryan, R. M. (2000). The "what" and "why" of goal pursuits: Human needs and the self-determination of behavior. Psychological Inquiry, 11, 227-268.

Deci, E. L., Vallerand, R. J., Pelletier, L. G., \&. Ryan, R. M. (1991). Motivation and education: The self-determination perspective. Educational Psychologist, 26, 325-346.

Ellis, S., Mendel, R., \& Nir, M. (2006). Learning from successful and failed experiences: The moderating role of kind of after-event review. Journal of Applied Psychology, 91(3), 669-680.

Garrison, D. R. \& Anderson, T. (2003). E-Learning in the 21st Century: A framework for research and practice. London: Routledge Falmer.

Garrison, D. R., Anderson, T. \& Archer, W. (2000). Critical inquiry in a text-based environment: Computer conferencing in higher education. The Internet and Higher Education, 2(2-3), 87-105.

Gottfried, A. E. (1985). Academic intrinsic motivation in elementary and junior high school students. Journal of Educational Psychology, $77,631-645$.

Greenberg, Z., \& Cohen, A. (2012). Implementation of "Learning from Success" Model on Learning Disabilities Students. Journal of Social Sciences 8(3), 459-466.

Henderlong, J \& Lepper, M. R. (2002). The effects of praise on children's intrinsic motivation: A review and synthesis. Psychological Bulletin, 128(5), 774-795.

Hidi, S., \& Harackiewicz, J. M. (2000). Motivating the academically unmotivated: A critical issue for the $21 s t$ century. 
Review of Educational Research, 70, 151-179.

Krapp, A., Hidi, S., \& Renninger, K. A. (1992). Interest, learning, and development. In K. A. Renninger, S. Hidi, \& A. Krapp (Eds.), The role of interest in learning and development, (pp. 3-25). Hillsdale, NJ: Lawrence Erlbaum Associates.

Kreber, C. (2005). Reflection on teaching and the scholarship of teaching: Focus on science instructors. Higher Education, 50(2), 323359.

Kruse, C. S. D. (2001). Learning communities of reform: Continuous improvement planning teams. Journal of Educational Administration, 39(4), 359-383.

Osterman, K. F. (2000). Students' need for belonging in the School Community. Review of Educational Research, 70, 323-367.

McKenzie, K., \& Schweitzer, R. (2001). Who succeeds at university? Factors predicting academic performance in first year Australian university students. Higher education research and development, 20(1), 21-33.

Oplatka, I. (2007). Managing emotions in teaching: toward an understanding of motion displays and caring as non-prescribed role elements. Teachers College Record, 109(6), 1374-1400.

Perkins, D. (1993). The connected curriculum. Educational Leadership, 51(2), 90-91.

Pintrich, P. R., \& Schunk, D. (2002). Motivation in education: Theory, research, and applications (2nd ed.). Upper Saddle, NJ: PrenticeHall, Inc.

Ryan, R. M. (1995). Psychological needs and the facilitation of integrative processes. Journal of Personality, 63, 397-427.

Schechter, C., Sykes, I. J., \& Rosenfeld, J. M. (2004). Learning from success: A leverage for transforming schools into learning communities. Planning and Changing, 35(3-4), 154-168.

Schechter, C., Sykes, I. J., \& Rosenfeld, J. M. (2008). Learning from success as leverage for school learning: Lessons from a national program in Israel. International Journal of Leadership in Education, 11(3), 301-318.

Schechter, C. (2010). Learning from success as leverage for a professional learning community: Exploring an alternative perspective of school improvement process. Teachers College Record, 112(1), 180-224.

Schon, D.A. (1987). Educating the reflective practitioner. New York: Basic Books.

Schon, D.A. (1991). (Ed). The reflective turn. New York: Teachers College, Columbia University.

Soric, E. (2009). Regulatory styles, causal attributions and academic achievement. School Psychology International, 30, $403-420$.

Sykes, I., Rosenfeld, J. M., \& Weiss, T. (2006). Learning from success as leverage for school-wide learning: The first method: Learning from success, the retrospective method. Jerusalem: Joint- the Brookdale Institute. (Hebrew)

Trigwell, K., Prosser, M. \& Waterhouse, F. (1999). Relations between teachers' approaches to teaching and students' approaches to learning. Higher Education, 37, 57-70.

Waugh, R. F. (2002). Creating a scale to measure motivation to achieve academically: Linking attitudes and behaviors using Rasch measurement. British Journal of Educational Psychology, 72, 65-86.

Weiner. B. (1989). Human motivation. Hillsdale, NJ: Erlbaum \& Associates Publishers.

Weiss,T., Gavish, T., Rosenfeld, J., Ellenbogen-Rankovits, S. \& Sykes, I. (2007). Learning from success as leverage for school-wide learning: The second method: From a learning question to a learning quest - The prospective method. Jerusalem: Joint- The Brookdale Institute. (Hebrew) 
